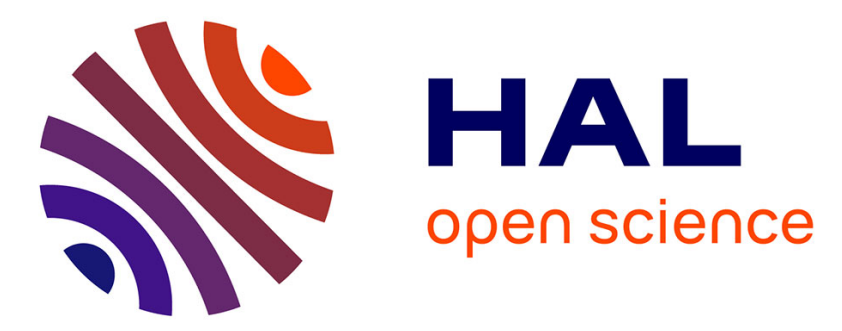

\title{
Piezothermal studies in the vicinity of the smectic A-nematic transition in 4'-n-octyloxy-4-cyanobiphenyl (8OCB)
}

\author{
R. Shashidhar, L. ter Minassian, B.R. Ratna, A.N. Kalkura
}

\section{To cite this version:}

R. Shashidhar, L. ter Minassian, B.R. Ratna, A.N. Kalkura. Piezothermal studies in the vicinity of the smectic A-nematic transition in 4'-n-octyloxy-4-cyanobiphenyl (8OCB). Journal de Physique Lettres, 1982, 43 (7), pp.239-242. 10.1051/jphyslet:01982004307023900 . jpa-00232039

\section{HAL Id: jpa-00232039 https://hal.science/jpa-00232039}

Submitted on 1 Jan 1982

HAL is a multi-disciplinary open access archive for the deposit and dissemination of scientific research documents, whether they are published or not. The documents may come from teaching and research institutions in France or abroad, or from public or private research centers.
L'archive ouverte pluridisciplinaire HAL, est destinée au dépôt et à la diffusion de documents scientifiques de niveau recherche, publiés ou non, émanant des établissements d'enseignement et de recherche français ou étrangers, des laboratoires publics ou privés. 
Classification

Physics Abstracts

$61.30 \mathrm{C}-64.70 \mathrm{E}-65.70$

\title{
Piezothermal studies in the vicinity of the smectic A-nematic transition in 4'-n-octyloxy-4-cyanobiphenyl (8OCB)
}

\author{
R. Shashidhar $\left({ }^{*}\right)\left({ }^{1}\right)$, L. Ter Minassian $(* *)$, B. R. Ratna $\left({ }^{* * *}\right)$ and A. N. Kalkura $(* * *)$ \\ $\left(^{*}\right)$ Department of Chemistry, Institute of Physical Chemistry, \\ University of Bochum, 4630 Bochum, Federal Republic of Germany \\ (**) Laboratoire de Chimie Physique, Université Pierre et Marie Curie, \\ 11, rue Pierre et Marie Curie, 75231 Paris Cedex 05, France \\ $\left({ }^{* *}\right)$ Raman Research Institute, Bangalore-560 080, India.
}

(Reçu le 18 janvier 1982, accepté le 15 février 1982)

\begin{abstract}
Résumé. - L'expansion thermique $(\alpha)$ de 4'-n-octyloxy-4-cyanobiphényl (8OCB) a été étudiée en fonction de la pression sur différentes lignes isothermes par la méthode piézothermique. A proximité de la transition $\alpha$ smectique A-nématique apparaît une anomalie qui devient moins prononcée lorsque la température augmente.

Abstract. - The thermal expansion ( $\alpha$ ) of 4'-n-octyloxy-4-cyanobiphenyl (8OCB) has been studied as a function of pressure along different isotherms by the piezothermal method. In the vicinity of the smectic A-nematic transition, $\alpha$ shows an anomaly which becomes less pronounced with increasing temperature.
\end{abstract}

1. Introduction. - Although the first observation of the re-entrant nematic behaviour in a pure compound was at high pressure [1], the subsequent observation of this behaviour at atmospheric pressure [2] has led to the fact that most of the experimental studies that are being conducted on re-entrant nematogens are almost exclusively atmospheric pressure experiments. In fact, apart from the $p-T$ diagrams of Cladis et al. [1, 3], the only other studies at high pressure on re-entrant nematics are an X-ray [4] study and some A.C. calorimetric studies [5, 6]. We report here measurements on the thermal expansion $(\alpha)$ of $4^{\prime}$-n-octyloxy-4-cyanobiphenyl (8OCB) as a function of pressure along 4 different isotherms by the piezothermal method.

2. Experimental. - The piezothermal or heat of compression method [7, 8] essentially consists of a measurement of a quantity of heat $Q$ liberated by a volume $V_{\mathrm{s}}$ of the sample under a pressure variation of $\Delta p$. This quantity of heat is directly related to the thermal expansion coefficient $\alpha$ of the sample by the relation $[9,10]$ :

$$
Q=-\left(\alpha-\alpha_{\mathrm{r}}\right) T V_{\mathrm{s}} \Delta p
$$

( ${ }^{1}$ ) Humboldt fellow and on leave of absence from the Raman Research Institute, Bangalore-560 080, India. 
where $\alpha_{\mathrm{r}}$ is the expansion coefficient of the containing material. The calorimeter used is a conventional flux calorimeter (SETARAM) adopted for high pressure experiments. The experimental set up which is the same as that used earlier for the study of the thermal expansion of water and some organic liquids, has already been described elsewhere [7, 8] and will not be repeated here. Essentially, the sample, contained in a pressure tubing and suspended inside the calorimeter, is compressed. The resulting heat liberated in the sample is measured as an emf by a set of 500 thermocouples which are electrically in series but thermally in parallel. The combined emf of the thermocouples is recorded and integrated as a function of time. The area under the " thermogram » [7] gives the quantity of heat $Q$ caused by a change of pressure $\Delta p$. The apparatus having been initially calibrated using an ideal gas like nitrogen (see reference [7] for details regarding the calibration procedure used), i.e. $\alpha_{\mathrm{r}}$ and $V_{\mathrm{s}}$ being pre-determined, $\alpha$ of the sample can be determined using equation (1). The absolute pressures and temperatures were measured to accuracies of \pm 0.5 bar and $\pm 0.01 \mathrm{~K}$ respectively. They were also maintained to the same accuracies. The relative accuracy in the determination of $\alpha$ is reckoned to be about $\pm 2 \%$.

3. Results and discussion. - The sample of $80 \mathrm{OCB}$ used in the present study was purchased from $\mathrm{BDH}$ England and was used without further purification. The transition temperatures at 1 bar were $67.0^{\circ} \mathrm{C}$ for the smectic A-nematic (A-N) and $81.0^{\circ} \mathrm{C}$ for the nematic-isotropic (N-I) transitions. The $p-T$ diagram, obtained using an optical cell [11], is given in figure 1. The maximum pressure of occurrence of the smectic A phase is $1.98 \mathrm{kbar}$ which is in good agreement with the earlier data of Cladis et al. [1] and Garland et al. [5]. The experiment has been conducted along 4 different isotherms, viz., 68.7, 71.4, 75.1 and $77.6^{\circ} \mathrm{C}$. Before commencing the experiment at any temperature, the system was allowed to attain thermal equilibrium for at least 24 hours. Then the pressure was increased very slowly to a pressure of about 200 bar above the A-N transition pressure at that temperature. Pressure was then decreased by small steps (a few bars) and the

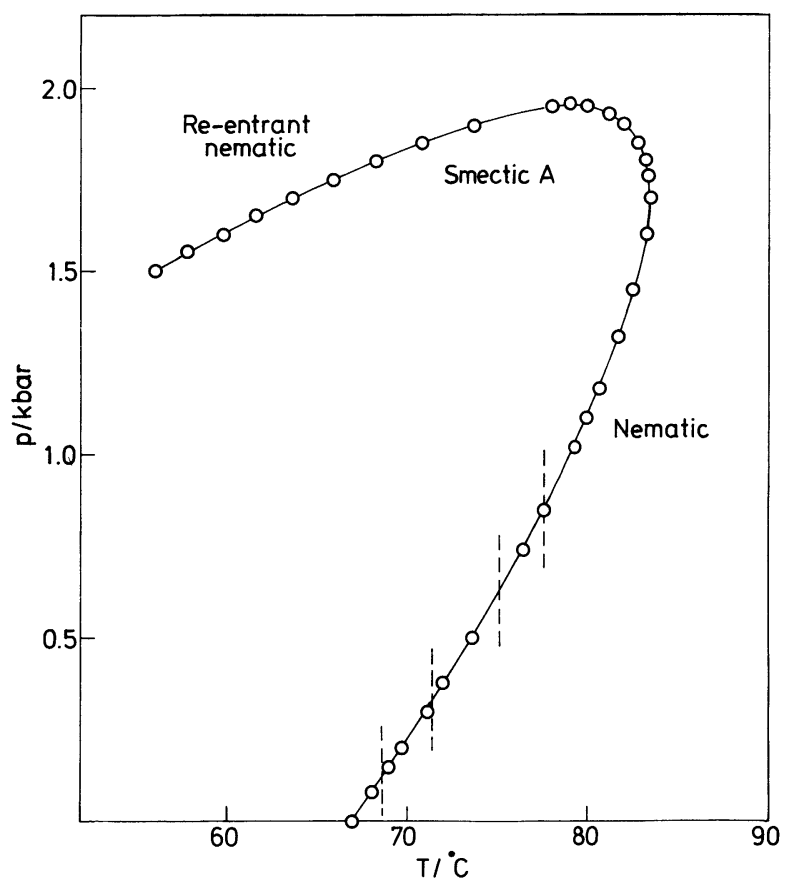

Fig. 1. $-p-T$ diagram for the smectic A-nematic transition of $8 \mathrm{OCB}$. The dashed lines indicate the temperatures at which the measurements of $\alpha$ have been made. 

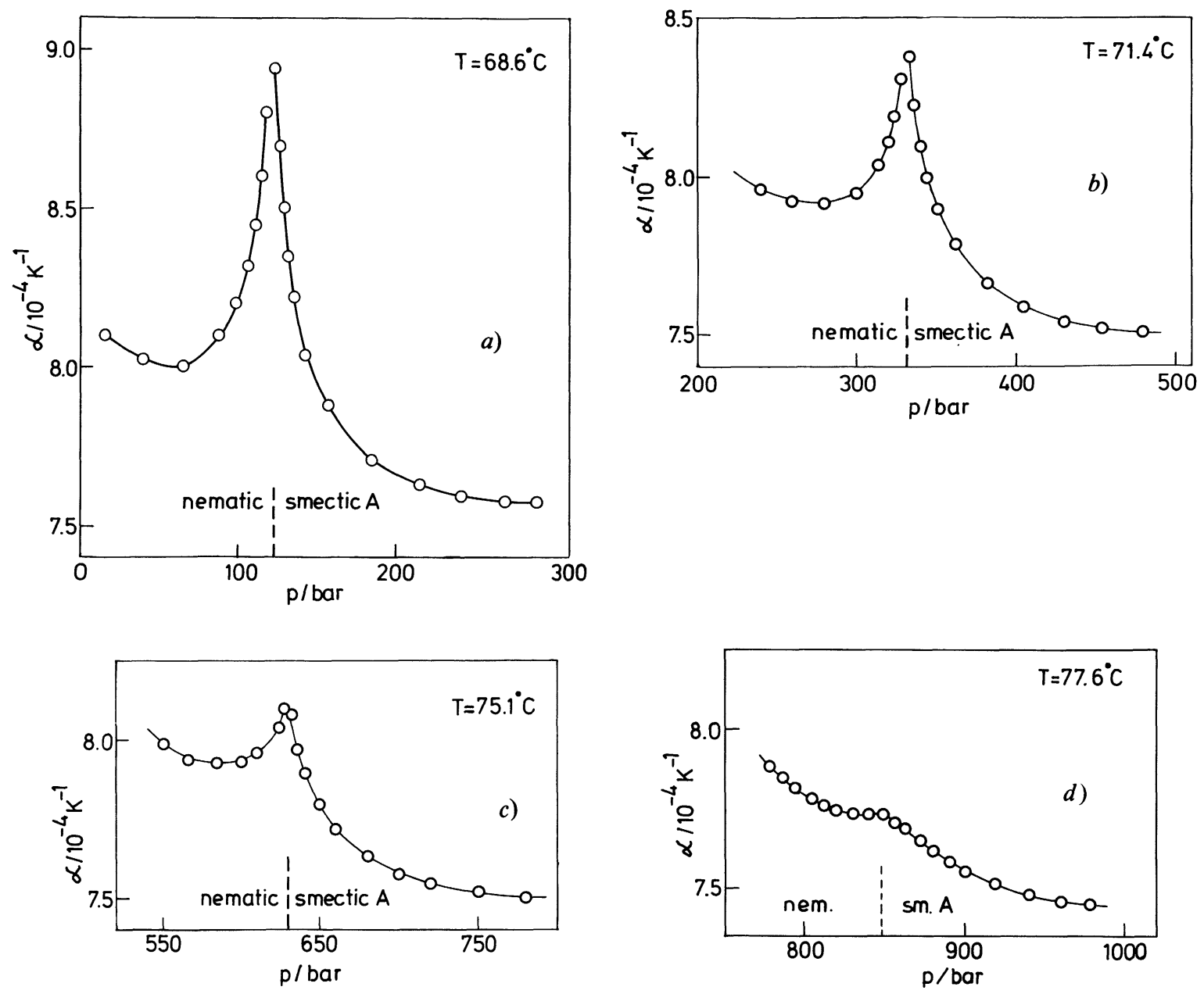

Fig. 2. - Variation of the thermal expansion $(\alpha)$ of $8 \mathrm{OCB}$ with pressure at 4 different isotherms : $(a) 68.6^{\circ} \mathrm{C}$; (b) $71.4^{\circ} \mathrm{C} ;(c) 75.1^{\circ} \mathrm{C}$ and $(d) 77.6^{\circ} \mathrm{C}$.

area of the potential versus time curve integrated at each step. Initially, at pressures not close to the A-N transition, the time necessary for each step was about $40 \mathrm{~min}$. However, in the vicinity of the A-N transition the recording and integration had to be carried out for much longer periods of time. No experiments could be conducted on the re-entrant nematic phase owing to the rapid crystallization of the supercooled smectic A phase.

Figures $2(a)-(d)$ show the thermal expansion versus pressure curves for the 4 different temperatures studied. $\alpha$ exhibits an anomaly at the A-N transition. The strength of this peak decreases with increasing temperature and at the highest temperature studied, viz., $77.6^{\circ} \mathrm{C}$, there is hardly any anomaly (Fig. 2(d)). Generally, it is far more difficult to achieve as fine a variation of pressure as of temperature. To that extent, we would like to emphasize that our experimental values of $\alpha$, particularly close to the A-N transition, do not have the precision required to make a good estimate of the exponent $(\beta)$ associated with the pressure variation of $\alpha$. Nevertheless, an attempt has been made to fit all the data points for $T=68.6^{\circ} \mathrm{C}$ to equations of the type :

$$
\alpha=a_{0}+p_{\mathrm{r}} a_{1}+A\left|p_{\mathrm{r}}\right|^{\beta}, \text { for } p<p_{0}
$$


and

$$
\alpha=a_{0}^{\prime}+p_{\mathrm{r}} a_{1}^{\prime}+A\left|p_{\mathrm{r}}\right|^{\beta}, \text { for } p>p_{0},
$$

where $a_{0}, a_{1}, a_{0}^{\prime}$ and $a_{1}^{\prime}$ are all adjustable parameters, $p_{0}$ is the $\mathrm{A}-\mathrm{N}$ transition pressure for

$$
T=68.6^{\circ} \mathrm{C},
$$

$p_{\mathrm{r}}=\left|\left(p-p_{0}\right)\right| / p$ is the reduced pressure. The base lines with respect to which the expansion coefficients have been evaluated for this fitting consist of two linear parts, one in the nematic and the other in the smectic A phases. The data points at pressures farthest from $p_{0}$ have been used to obtain these two linear base line parts which intersect at the A-N transition pressure $p_{0}$. This appears to yield a reasonably good fit over the entire range of pressure investigated, giving a value of 0.22 for the exponent $\beta$. Attempts were also made to fit the same set of data points in another manner, i.e., by taking the two base line parts to have a discontinuity (and not intersect) at $p_{0}$. Such a fitting procedure gave a very poor fit, indicating thereby that the $\mathrm{A}-\mathrm{N}$ transition may be more aptly described as a higher order transition than a first order one.

It may also be mentioned that an integration of the $\alpha$ versus pressure curve essentially leads to a term which should be a function of entropy (see e.g. Ref. [7]). Thus it is not surprising that the trends of our $\alpha$ versus pressure curves with increasing temperature resemble generally the $C_{p}$ versus temperature curves with increasing pressure obtained for the same compound by Garland et al. $[5,6]$. A detailed thermodynamic analysis of our piezothermal data is being carried out and will be published separately.

Acknowledgments. - The authors are thankful to Mr. F. Milliou for his assistance in experimentation. Thanks are also due to Prof. G. M. Schneider for several illuminating discussions and to Dr. U. Deiters for the computations. One of us (R.S.) is grateful to Alexander von HumboldtStiftung for the award of a fellowship.

\section{References}

[1] Cladis, P. E., Bogardus, R. K., Daniels, W. B. and Taylor, G. N., Phys. Rev. Lett. 39 (1977) 720.

[2] Hardouin, F., Sigaud, G., Achard, M. F. and Gasparoux, H., Phys. Lett. 71A (1979) 347. Madhusudana, N. V., Sadashiva, B. K. and Moodithaya, K. P. L., Curr. Sci. 48 (1979) 613.

[3] Cladis, P. E., Bogardus, R. K. and Aadsen, D., Phys. Rev. A 18 (1978) 2292.

[4] Chandrasekhar, S., Shashidhar, R. and Rao, K. V., in "Advances in Liquid Crystal Research and Application ", Proc. Third Liq. Cryst. Socialist Countries, Budapest, August 1979.

[5] Garland, G. W., Kasting, G. B. and Lushington, K. J., Phys. Rev. Lett. 43 (1979) 1420.

[6] Kasting, G. B., Lushington, K. J. and Garland, G. W., Phys. Rev. B 22 (1980) 321.

[7] Ter Minassian, L. and Pruzan, Ph., J. Chem. Thermodynamics 9 (1977) 375.

[8] Ter Minassian, L., Pruzan, Ph. and Soulard, A., J. Chem. Phys. 75 (1981) 3064.

[9] Ter Minassian, L., Petit, J. C., Nguyen Van Keit and Brunard, C., J. Chim. Phys. 67 (1970) 265 ; see also :

Petit, J. C. and Ter Minassian, L., J. Chem. Thermodynamics 6 (1974) 1139.

[10] Fuchs, A. H., Pruzan, Ph. and Ter Minassian, L., J. Phys. Chem. Solids 40 (1979) 369.

[11] Kalkura, A. N., Ph. D. Thesis, University of Mysore (under preparation). 